\title{
SISTEM PAKAR UNTUK PERLINDUNGAN TANAMAN PADI MENGGUNAKAN METODE FORWARD CHAINING
}

\author{
Joko Kus wanto ${ }^{1}$ \\ ${ }^{1}$ Program Studi Informatika, Fakultas Teknik dan Komputer, Universitas Baturaja \\ Jl. Ki Ratu Penghulu No. 02301 Karang Sari Telepon (0735) 326122 Fax. 321822 \\ Baturaja - 32113 OKU Sumatera Selatan \\ jokokuswanto@unbara.ac.id
}

\begin{abstract}
Abstrak
Tujuan dari penelitian ini adalah membuat aplikasi sistem pakar untuk perlindungan tanaman padi menggunakan metode forward chaining. Sistem pakar ini dapat digunakan dan membantu ahli pertanian, petani maupun orang awam untuk proses diagnosa hama dan penyakit pada tanaman padi dengan cara memasukkan gejala-gejala kerusakan yang terjadi pada tanaman padi serta mampu memberikan informasi pengetahuan tentang hama dan penyakit tersebut sehingga didapatkan solusi berupa pengendalian dari hama dan penyakit. Sistem ini dikembangkan untuk menyimpan pengetahuan keahlian seorang pakar tanaman padi, sehingga nantinya sistem yang dikembangkan ini dapat dijadikan asisten pandai untuk membantu memecahkan permasalahan pada tanaman padi. Dari hasil pengujian yang telah dilakukan, menunjukan bahwa sistem pakar sudah layak digunakan untuk mendiagnosis hama dan penyakit pada tanaman padi.
\end{abstract}

Kata-kata kunci: sistem pakar, padi, forward chaining

\begin{abstract}
The purpose of this research is making an application expert systemfor the protection of rice plants using a method of forward chaining. Expert system can be used and help agricultural, farmers and a layman to the process of the diagnosis pest and disease in rice plants by entering the symptom that occurs in rice plants and able to provide information knowledge of the pest and disease or controlled by solution of pest and disease. This system developed for storing knowledge skill of a experts the rice crop, so that the system which developed as an assistant smart enough to help solve the problem in the rice crop. From the tests has done, suggests that expert system was already feasible used to diagnose pest and disease in rice.
\end{abstract}

Keywords: expert system, rice, forward chaining 


\section{PENDAHULUAN}

Kebutuhan setiap manusia akan sadang, pangan, dan papan semakin hari semakin meningkat. Terutama kebutuhan pangan yang merupakan titik awal proses perkembangan manusia. Berbagai macam makanan dikonsumsi oleh manusia, baik makanan pokok maupun pelengkap yang semuanya sangat dibutuhkan sebagai sumber energi untuk menjalankan berbagai aktifitas. Salah satu makanan pokok bagi sebagian besar masyarakat Indonesia adalah nasi. Melihat begitu pentingnya nasi sebagai makanan pokok, maka padi yang merupakan bahan dasarnya pun perlu diperhatikan, baik dari jenis, kualitas dan jumlahnya.

Untuk mendapatkan hasil padi yang sesuai dengan kebutuhan konsumen, maka diperlukan adanya pengolahan lahan pertanian, pemupukan maupun perlindungan. Perlindungan itu sendiri yaitu melindungi tanaman dari serangan hama dan penyakit, serta melakukan pemberantasan terhadap hama dan penyakit tersebut. Dalam hal ini, sangat diperlukan informasi atau pengetahuan dari seorang ahli pertanian khususnya tanaman padi. Namun secara kondisi yang ada sekarang ini, ketersediaan dan keberadaan ahli pertanian tidak selalu ada sehingga menjadi penghambat saat ada petani yang ingin bertanya tentang permasalahan pertanian khususnya padi.

Berdasarkan hal tersebut menunjukkan bahwa perlu adanya suatu sistem yang dapat dijadikan sebagai alat untuk mempermudah petani mendapatkan informasi dan melakukan konsultasi mengenai perlindungan tanaman padi dari hama dan penyakit. Sebuah sistem yang dapat mengidentifikasi penyakit tanaman padi dengan mensubstitusikan kemampuan seorang pakar ke dalam program komputer sehingga bisa juga disebut sebagai sistem pakar (Irsan, 2015). Dengan adanya sistem pakar, pihak yang bukan pakar dapat menyelesaikan masalah yang biasa diselesaikan oleh pakar.

Sistem pakar telah banyak diterapkan dalam beberapa masalah, seperti untuk mendiagnosa penyakit ginjal pada manusia (Azhar, 2014), diagnosa hama anggek (Yuwono, 2017), Diagnosa Pulmonary TB (Novianti, 2018), Tanaman Melon (Pramudeka, 2018).

Sistem pakar menggunakan metode inferensi forward chaining diterapkan pada pemilihan tipe perumahan (Maliki, 2018) kerusakan komputer (Kuswanto, 2020). Penelitian ini bertujuan menerapkan metode inferensi forward chaining untuk perlindungan tanaman padi.

\section{METODE PENELITIAN}

Metode yang dilakukan dalam penelitian ini adalah metode inferensi. Inferensi merupakan otak dari sistem pakar, berupa perangkat lunak yang melakukan tugas inferensi penalaran sistem pakar, biasa dikatakan sebagai mesin pemikir 
(thinking machine) (Andreanus, 2017). Pada dasarnya inferensilah yang mencari solusi dari suatu permasalahan. Ada 2 cara yang dapat dikerjakan dalam melakukan inferensi, yaitu: forward chaining merupakan grup dari multiple inferensi yang melakukan pencarian dari suatu masalah kepada solusinya, backward chaining menggunakan pendekatan goal-driven, dimulai dari ekspektasi apa yang diinginkan terjadi (hipotesis), kemudian mencari bukti yang mendukung (atau kontradiktif) dari ekspektasi tersebut (Honggowibowo 2009).

Gambar 1 menunjukkan bagaimana cara kerja metode inferensi runut maju (Sapri, 2014).

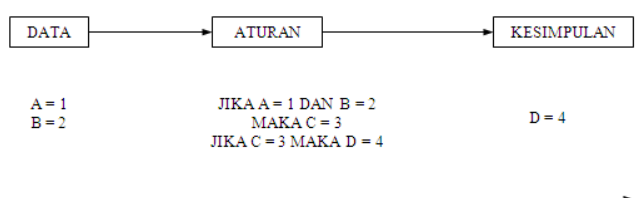

Gambar 1. Runut Maju

Metode inferensi runut maju cocok digunakan untuk menangani masalah pengendalian (controlling) dan peramalan (prognosis). Berikut contoh inferensi dengan menggunakan inferensi runut maju (Yahya, 2011):

JIKA penderita terkena penyakit epilepsi idiopatik dengan $\mathrm{CF}$ antara 0,4 s/d 0,6

MAKA berikan obat carbamazepine

Gambar 2 menunjukkan bagaimana alur proses kerja metode inferensi forward chaining.

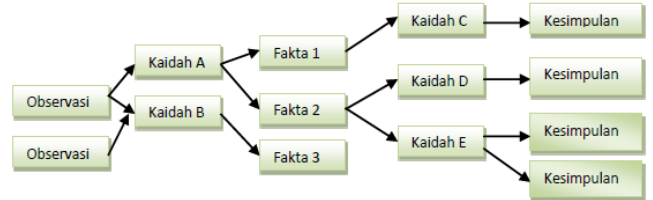

Gambar 2. Alur proses kerja Metode Forward Chaining

Proses forward chaining dimulai dengan memberikan list indikasi atau keadaan yang sedang dialami pada saat melakukan konsultasi lalu diolah melalui proses penentuan solusi sehingga dapat diperoleh solusi yaitu cara pengendalian perusak (hama dan penyakit) dari jenis perusak dan gejala kerusakan yang telah dipilih. Untuk melihat bagaimana langkah konsultasi dapat di lihat melalui Gambar 3.

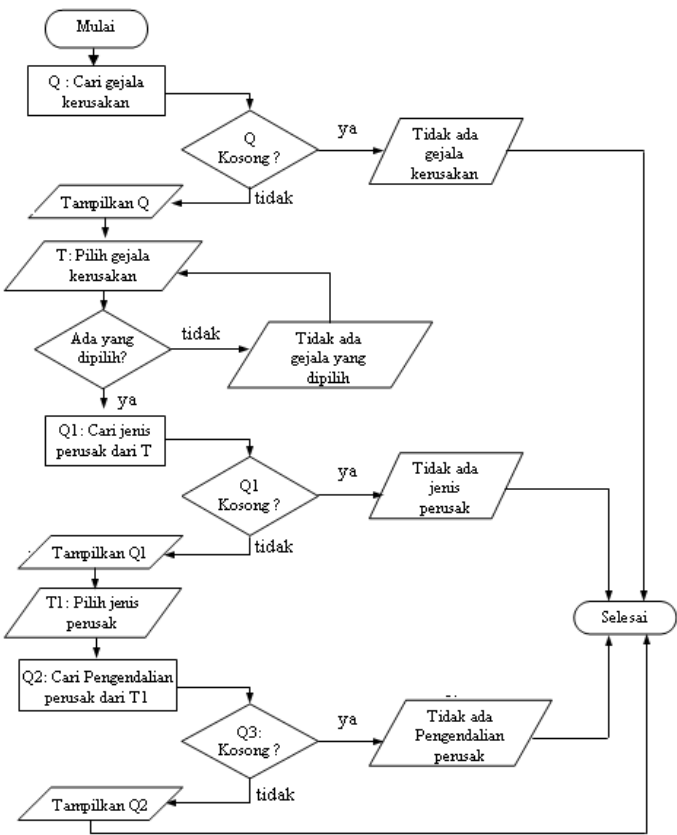

Gambar 3. Flowchart Konsultasi

Data yang digunakan untuk pembuatan sistem berdasarkan 
informasi dari ahli atau expert baik dari jenis hama dan penyakit, gejala dan pengendaliannya. Data yang diperoleh dari ahli dikelompokkan dan diberi kode sehingga mempermudah proses diagnosa saat melakukan konsultasi. Adapun datadata tersebut dapat dilihat pada Tabel 1

Tabel 1. Data gejala dari hama dan penyakit

\begin{tabular}{|ll|}
\hline Kode & Nama Gejala \\
\hline G001 & $\begin{array}{l}\text { Padi mengalami kerusakan } \\
\text { sejak dari pesemaian hingga } \\
\text { dalam penyimpanan }\end{array}$ \\
\hline G002 & $\begin{array}{l}\text { Tanaman yang terserang } \\
\text { banyak bekas potongan dan } \\
\text { terdapat bekas gigitan }\end{array}$ \\
\hline G003 & $\begin{array}{l}\text { Kerusakan tanaman banyak } \\
\text { kelihatan pada pagi hari }\end{array}$ \\
\hline G004 & $\begin{array}{l}\text { Daun dan batang hilang dari } \\
\text { pertanaman }\end{array}$ \\
\hline G005 & $\begin{array}{l}\text { Banyak potongan daun dan } \\
\text { batang terlihat mengambang }\end{array}$ \\
\hline G006 & $\begin{array}{l}\text { Padi banyak terserang saat } \\
\text { fase matang susu sampai } \\
\text { pemasakan biji (sebelum } \\
\text { panen) }\end{array}$ \\
\hline G007 & $\begin{array}{l}\text { Banyak biji hampa dan } \\
\text { hilang }\end{array}$ \\
\hline G008 & $\begin{array}{l}\text { Banyaknya kupu-kupu kecil } \\
\text { berwarna putih pada sore } \\
\text { dan malam hari }\end{array}$ \\
\hline G009 & $\begin{array}{l}\text { Banyak daun padi muda } \\
\text { menguning dan mati }\end{array}$ \\
\hline G010 & $\begin{array}{l}\text { Padi yang sedang bunting } \\
\text { buliran padinya keluar, } \\
\text { berguguran, gabah-gabah } \\
\text { kosong dan berwarna keabu- } \\
\text { abuan }\end{array}$ \\
\hline
\end{tabular}

\begin{tabular}{|c|c|}
\hline Kode & Nama Gejala \\
\hline G011 & $\begin{array}{l}\text { Banyak binatang kecil di } \\
\text { tempat lembab, gelap dan } \\
\text { teduh }\end{array}$ \\
\hline G012 & $\begin{array}{l}\text { Banyak malai dan bulir padi } \\
\text { yang hampa. }\end{array}$ \\
\hline G013 & Tanaman kerdil \\
\hline G014 & $\begin{array}{l}\text { Tanaman padi terserang } \\
\text { pada fase masak susu }\end{array}$ \\
\hline G015 & $\begin{array}{l}\text { Terdapat bekas tusukan dan } \\
\text { pecah }\end{array}$ \\
\hline G016 & $\begin{array}{l}\text { Daun menggulung rapat } \\
\text { seperti daun bawang }\end{array}$ \\
\hline G017 & $\begin{array}{l}\text { Daun memucat, menguning, } \\
\text { akhirnya kering }\end{array}$ \\
\hline G018 & $\begin{array}{l}\text { Daun terpotong seperti } \\
\text { digunting }\end{array}$ \\
\hline G019 & $\begin{array}{l}\text { Tanaman padi yang diserang } \\
\text { kebanyakan berasal dari } \\
\text { bibit-bibit lemah }\end{array}$ \\
\hline G020 & $\begin{array}{l}\text { Tanaman terpotong pada } \\
\text { pangkal batang }\end{array}$ \\
\hline G021 & $\begin{array}{l}\text { Rusaknya akar muda dan } \\
\text { bagian pangkal tanaman } \\
\text { yang berada di bawah tanah }\end{array}$ \\
\hline G022 & $\begin{array}{l}\text { Tanaman padi muda yang } \\
\text { diserang mati sehingga } \\
\text { terlihat adanya spot-spot } \\
\text { kosong di sawah }\end{array}$ \\
\hline G023 & $\begin{array}{l}\text { Warna daun menjadi } \\
\text { kemerahan, atau daun-daun } \\
\text { luar menguning, akhirnya } \\
\text { menjadi kering }\end{array}$ \\
\hline G024 & $\begin{array}{l}\text { Pertumbuhan panjang } \\
\text { terhenti, sehingga daun-daun } \\
\text { teratur seperti kipas }\end{array}$ \\
\hline G025 & $\begin{array}{l}\text { Bunga tetap tersimpan di } \\
\text { dalam upih-upih daun }\end{array}$ \\
\hline G026 & $\begin{array}{l}\text { Ujung daun } \text { berwarna } \\
\text { kuning, hijau jingga atau } \\
\text { kuning cokelat }\end{array}$ \\
\hline
\end{tabular}




\begin{tabular}{|ll|}
\hline Kode & Nama Gejala \\
\hline G027 & $\begin{array}{l}\text { Pada daun yang masih muda } \\
\text { terdapat bintik-bintik cokelat }\end{array}$ \\
\hline G028 & $\begin{array}{l}\text { Pada daun terdapat bercak } \\
\text { klorotis }\end{array}$ \\
\hline G029 & $\begin{array}{l}\text { Daunnya berbintik-bintik } \\
\text { kecil berwarna cokelat hitam }\end{array}$ \\
\hline G030 & $\begin{array}{l}\text { Tanaman yang terserang } \\
\text { justru malah banyak } \\
\text { anakanya }\end{array}$ \\
\hline G031 & Daunnya sempit dan lancip \\
\hline G032 & $\begin{array}{l}\text { Daun memuth kemudian } \\
\text { menguning }\end{array}$ \\
\hline G033 & $\begin{array}{l}\text { Pada satu rumpun terdapat } \\
\text { banyak anakan }\end{array}$ \\
\hline G034 & $\begin{array}{l}\text { Pada pucuk daun bagian } \\
\text { atas, terdapat bercak-bercak } \\
\text { kuning dan bercak-bercak } \\
\text { tersebut sejajar dengan } \\
\text { tulang daun }\end{array}$ \\
\hline G035 & $\begin{array}{l}\text { Pada serangan yang berat, } \\
\text { penyakitnya merusak titik } \\
\text { tumbuh, dan menyebabkan } \\
\text { matinya tanaman itu }\end{array}$ \\
\hline
\end{tabular}

Setelah pemberikan kode pada data gejala, selanjutnya adalah pemberian kode pada perusak yang dalam hal ini adalah data tentang hama dan penyakit. Adapun pengkodean dari hama dan penyakit tersebut ditunjukkan pada Tabel 2 .

Tabel 2. Data hama dan penyakit

\begin{tabular}{|lll|}
\hline Kode & Nama Hama dan Penyakit \\
\hline J001 & Tikus & \\
\hline J002 & Keong Mas & \\
\hline J003 & Burung & \\
\hline J004 & $\begin{array}{l}\text { Sundep } \\
\text { Innotata })\end{array}$ & (Scirpophaga \\
\hline J005 & Ulat & \\
\hline
\end{tabular}

\begin{tabular}{|ll|}
\hline Kode & Nama Hama dan Penyakit \\
\hline J006 & Wereng \\
\hline J007 & $\begin{array}{l}\text { Walang Sangit (Leptocorixa } \\
\text { Acuta) }\end{array}$ \\
\hline J008 & $\begin{array}{l}\text { Ganjur } \\
\text { Eryzae) }\end{array}$ \\
\hline J009 & $\begin{array}{l}\text { Hama Pachydiplosis } \\
\text { Depunctalis) }\end{array}$ \\
\hline J010 & Orong-Orong \\
\hline J011 & Penyakit Mentek \\
\hline J012 & Penyakit Tugro \\
\hline J013 & Penyakit Grassy Stunt \\
\hline J014 & $\begin{array}{l}\text { Penyakit Kerdil Kuning } \\
\text { (Yellow Dwarf) }\end{array}$ \\
\hline J015 & Penyakit Kresek \\
\hline
\end{tabular}

Setelah pemberikan kode pada data gejala dan perusak selanjutnya adalah membuat rule, dimana rule yang dibuat akan diterapkan pada sistem saat konsultasi sesuai dengan metode runut maju (forward chaning) seperti pada Tabel 3 .

Tabel 3. Rule hama dan penyakit

\begin{tabular}{|ll|}
\hline Kode & Rule \\
\hline R1 & $\begin{array}{l}\text { IF G001 AND G002 AND } \\
\text { G003 THEN J001 }\end{array}$ \\
\hline R2 & $\begin{array}{l}\text { IF G004 AND G005 THEN } \\
\text { J002 }\end{array}$ \\
\hline R3 & $\begin{array}{l}\text { IF G006 AND G007 THEN } \\
\text { J003 }\end{array}$ \\
\hline R4 & $\begin{array}{l}\text { IF G008 AND G009 AND } \\
\text { G010 THEN J004 }\end{array}$ \\
\hline R5 & IF G002 THEN J005 \\
\hline R6 & $\begin{array}{l}\text { IF G011 AND G012 AND } \\
\text { G013 THEN J006 }\end{array}$ \\
\hline R7 & $\begin{array}{l}\text { IF G014 AND G012 AND } \\
\text { G015 THEN J007 }\end{array}$ \\
\hline R8 & $\begin{array}{l}\text { IF G016 AND G017 THEN } \\
\text { J008 }\end{array}$ \\
\hline
\end{tabular}




\begin{tabular}{|lll|}
\hline Kode & Rule \\
\hline R9 & IF G018 AND G019 THEN \\
& J009 \\
\hline R10 & IF G020 AND G021 AND \\
& G022 THEN J010 & \\
\hline R11 & IF G013 AND G023 AND \\
& G024 AND G025 THEN \\
& J011 \\
\hline R12 & IF G013 AND G026 AND \\
& G027 THEN J012 \\
\hline R13 & IF G028 AND G029 AND \\
& G030 AND G013 AND \\
& G031 THEN J013 \\
\hline R14 & IF G032 AND G033 AND \\
& G013 THEN J014 \\
\hline R15 & IF G034 AND G035 THEN \\
& J015 \\
\hline
\end{tabular}

\section{HASIL PENELITIAN DAN PEMBAHASAN}

Tahap berikutnya implementasi sistem berupa konsultasi. Untuk melakukan konsultasi, tahap pertama yang dilakukan oleh sistem adalah menampilkan semua daftar gejala yang digunakan sebagi acuan dalam data basis aturan. Setelah memilih gejala, mesin akan melanjutkan ke proses diagnosa untuk menentukan jenis hama dan penyakit, mesin inferensi menggunakan metode penelusuran maju. Data-data gejala yang dipilih pengguna, dijadikan acuan untuk menentukan kemungkinan indikasi hama dan penyakit. Proses selanjutnya akan melakukan penelusuran terhadap saran tentang bagaimana melakukan pengendalian terhadap hama dan penyakit. Tampilan sistem pakar perlindungan tanaman padi dari hama dan padi adalah sebagai berikut:

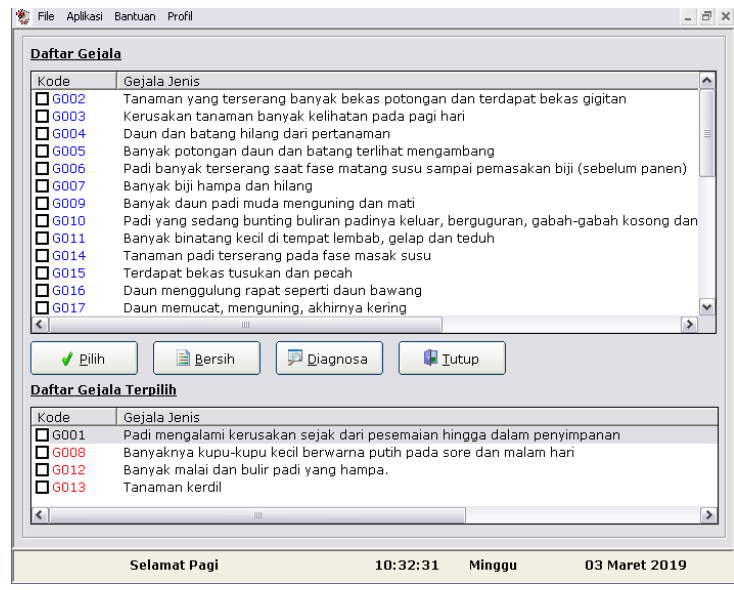

Gambar 4. Tampilan Daftar Gejala

Gambar 5 akan menampilkan jenis perusak dan besarnya presentase sesuai dengan gejala-gejala yang telah dipilih pada tampilan gejala yang ditunjukkan Gambar 4.

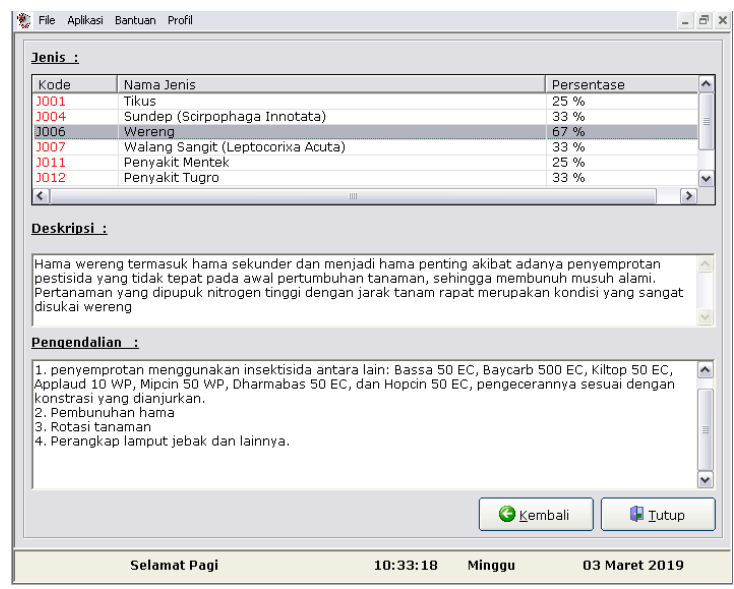

Gambar 5. Tampilan Hasil Konsultasi

\section{Bersarnya} presentase didapatkan berdasarkan banyaknya jumlah gejala-gejala yang telah dimasukkan pada basis aturan yaitu 
pada aturan-gejala. Adapun perhitungan besarnya presentase perusakn adalah sebagai berikut:

$\mathrm{BP}=\mathrm{m} / \mathrm{n} \times 100 \%$

Ket:

$\mathrm{BP}=$ Besarnya Presentase

$\mathrm{m} \quad=$ Jumlah gejala yang dipilih saat melakukan konsultasi

$\mathrm{n}=$ Jumlah gejala pada basis aturan

Contoh perhitungan secara manual:

Gejala yang dipilih:

1. G001 - Padi mengalami kerusakan sejak dari pesemaian hingga dalam penyimpanan

2. G008 - Banyaknya kupu-kupu kecil berw arna putih pada sore dan malam hari

3. G012 - Banyak malai dan bulir padi yang hampa.

4. G013 - Tanaman kerdil

Gejala yang ada dalam basis aturan: berjumlah 3 gejala

1. G011 - Banyak binatang kecil di tempat lembab, gelap dan teduh

2. G012 - Banyak malai dan bulir padi yang hampa.

3. G013 - Tanaman kerdil

Perhitungan:

$$
\begin{array}{r}
\text { J006 }(\text { Wereng })=2 / 3 \times 100 \% \\
=67 \%
\end{array}
$$

Perbandingan hasil pengujian dengan sistem pakar dan diagnosis pakar adalah pada Tabel 4 dan Tabel 5 berikut ini:
Tabel 4. Gejala Kerusakan

\begin{tabular}{|l|l|lr|}
\hline No & Kode & Gejala \\
\hline 1 & G002 & $\begin{array}{l}\text { Tanaman yang } \\
\text { terserang } \\
\text { bekas potongan dan } \\
\text { terdapat bekas gigitan }\end{array}$ \\
\hline 2 & G003 & $\begin{array}{l}\text { Kerusakan tanaman } \\
\text { banyak kelihatan pada } \\
\text { pagi hari }\end{array}$ \\
\hline 3 & G004 & $\begin{array}{l}\text { Daun dan batang } \\
\text { hilang dari } \\
\text { pertanaman }\end{array}$ \\
\hline
\end{tabular}

Tabel 5. Perbandingan hasil konsultasi

\begin{tabular}{|l|l|}
\hline Sistem Pakar & Pakar \\
\hline Ulat $100 \%$ & Ulat \\
\hline
\end{tabular}

\section{KESIMPULAN DAN SARAN}

Sistem pakar untuk perlindungan tanaman padi ini di kembangkan menggunakan metode forward chaining. Sistem pakar ini dapat digunakan dan membantu proses diagnosa hama dan penyakit pada tanaman padi dengan cara memasukkan gejala-gejala kerusakan yang terjadi pada tanaman padi serta mampu memberikan informasi pengetahuan tentang hama dan penyakit tersebut. Sistem ini dikembangkan untuk menyimpan pengetahuan keahlian seorang pakar tanaman padi, sehingga nantinya sistem yang dikembangkan ini dapat dijadikan asisten pandai untuk membantu memecahkan permasalahan pada tanaman padi. 


\section{DAFTAR PUSTAKA}

Anton Setiawan Honggowibowo, "Sistem Pakar Diagnosa Penyakit Tanaman Padi Berbasis Web Dengan Forward dan Backward Chaining," Jurnal Telkomnika Vol. 7 No. 3, Desember 2009: 187-194.

\section{Dito Rizki Pramudeka, Nurul Hidayat, Randy Cahya Wihandika, "Diagnosis Penyakit Tanaman Melon Menggunakan Promethee," Jurnal Pengembangan Teknologi Informasi dan Ilmu Komputer Vol. 2, No. 12, Desember 2018: 7386-7393.}

Doddy Teguh Yuwono, Abdul Fadlil, Sunardi, "Penerapan Metode Forw ard Chaining Dan Certainty Factor Pada Sistem Pakar Diagnosa Hama Anggrek Coelogyne Pandurata," Kumpulan jurnaL Ilmu Komputer (KLIK) Volume 04, No.02 September 2017: 136145.

Jonhar Lucky Adrianus Matheus, "Aplikasi Sistem Pakar Identifikasi Penyakit Tanaman Padi Dengan Metode Forward Chaining Berbasis Android," Skripsi, Universitas Lampung, 2017.

Kuswanto, Joko, "Sistem Pakar Kerusakan Hardware
Komputer", Jurnal INTECH

Vol. 1, No. 1, 2020: 17-23.

M. Irsan, Vidiyono Novian Pratama, Muhammad Fakih, "Sistem Pakar Identifikasi Penyakit Tanaman Padi Di Balai Penyuluhan Pertanian Sepatan Tangerang” Konferensi Nasional Sistem \& Informatika, STMIK STIKOM Bali, 9-10 Oktober 2015.

Nita Novianti, Denny Pribadi, Rizal Amegia Saputra, "Sistem Pakar Diagnosa Pulmonary TB Menggunakan Metode Fuzzy Logic," Jurnal Informatika Vol. 5 No. 2, September 2018, pp 228-236.

Ona Maliki, Fandi Dangkua, " Sistem Pakar Tipe Perumahan Menggunakan Metode Forward Chaining," Jurnal Informatika UPGRIS Vol. 4, No. 2, 2018: 150-157.

Samsilul Azhar, Herlina Latipa Sari, Leni Natalia Zulita, "Sistem Pakar Penyakit Ginjal Pada Manusia Menggunakan Metode Forward Chaining," Jurnal Media Infotama Vol. 10 No. 1, Februari 2014: 16-26.

Sapri, "Penerapan Sistem Pakar Untuk Diagnosa Penyakit Pada Manusia Disebabkan Oleh Nyamuk Dengan Metode Forward Chaining,".Jurnal 
Ilmiah MATRIK, Vol.16 No.2, Agustus 2014:145-162.

Yahya Nur Ifriza dan Djuniadi, "Perancangan Sistem Pakar Penyuluh Diagnosab Hama Padi dengan Metode Forward Chaining," Jurnal Teknik Elektro Vol. 7 No. 1 Januari Juni 2015: 30-36. 